\title{
Population aging and the probability of saving: a life cycle analysis of the Brazilian case
}

Envelhecimento populacional e probabilidade de poupar: uma análise do ciclo de vida do caso brasileiro

\author{
Pedro Tonon Zuanazzi(1) \\ Adelar Fochezatto (2) \\ (1) Secretaria de Planejamento, Governança e Gestão do \\ Rio Grande do Sul \\ (2) Pontifícia Universidade Católica do Rio Grande do Sul
}

\begin{abstract}
This study analyzes the life cycle of private individuals' savings in Brazil, reflecting on how the proportion of savers changes as the population ages. To this end, we employ a multinomial logit model to compare the probability of savings and dissavings for individuals, according to their ages, based on data from the Household Budget Surveys (HBS) of 2002-2003 and 2008-2009. The results confirm a greater incidence of savers among middle-aged adults and a greater percentage of dissavers among the elderly. However, given the age structure of the Brazilian population, demographic change is still expected to result in an increase in the number of net savers in the coming years.
\end{abstract}

\section{Keywords}

savings, life cycle, Brazil, household budget surveys.

JEL Codes J10, J14, G51.

\section{Resumo}

Este estudo analisa a poupança no ciclo de vida das pessoas no Brasil, refletindo sobre como a proporção de poupadores muda com o envelhecimento da população. Para tanto, utilizamos um modelo logit multinomial para comparar a probabilidade de poupança e não poupança para os indivíduos, de acordo com a idade, com base nos dados das Pesquisas de Orçamentos Familiares (POF) de 2002-2003 e 2008-2009. Os resultados confirmam uma maior incidência de poupadores entre os adultos de meia-idade e um maior percentual de não poupadores entre os idosos. No entanto, dada a estrutura etária da população brasileira, a mudança demográfica ainda deve resultar em um aumento líquido no número de poupadores nos próximos anos.

\section{Palavras-chave}

poupança, ciclo de vida, Brasil, pesquisa de orçamentos familiares.

Códigos JEL J10, J14, G51. 


\section{Introduction}

Savings is a key macroeconomic variable, despite theoretical controversies about its real role in economic growth. This issue has drawn even more attention since the Solow (1956) growth model was proposed, which argues that, holding technology constant, economic growth will be determined by a country's population growth rate and national savings rate. Subsequently, other models have continued to include savings among the variables that influence economic growth.

The demographic transition is especially significant in this context because household savings, an important component of national savings, will be directly impacted by population aging. This relationship began to receive attention in the mid- $20^{\text {th }}$ century, when two closely related theories linking the age of individuals to their savings and consumption behavior became prominent: the life cycle hypothesis (Modigliani e Ando, 1957; Ando e Modigliani, 1963) and the permanent income hypothesis (Friedman, 1957). Both assume that individuals seek to maximize their utility through a consumption profile compatible with their lifetime earnings.

Because consumption needs and income vary with an individual's age, the life cycle hypothesis holds that young people's consumption needs exceed their income, mainly due to education and housing expenses, while in adult middle age, higher incomes allow individuals to save more. Finally, during retirement, reduced income requires individuals to spend the savings they have accumulated during middle age. According to the permanent income hypothesis, individuals would prefer to distribute their consumption uniformly over time without having to reduce it because of lower income during retirement. Therefore, it states that they consume only that portion of their income that will persist over their lifetime. In other words, just as in the life cycle model, adults will save during the period of their maximum income.

In light of the life cycle model and given the rapid demographic transition Brazil is currently experiencing, with a marked reduction in fertility and mortality rates in recent decades, the aim of the present study is to estimate the effect that age has on the probability that individuals will be savers or dissavers. This makes it possible to reflect on the effects of the demographic transition on individuals' private savings and national savings. To accomplish this, we analyzed the Household Budget Surveys 
(HBS) of 2002-2003 and 2008-2009, with respect to trends over time, and the results are compared with the existing literature.

\section{Review of the literature}

Leff (1969) was among the pioneers in empirical studies that sought to examine the relationship between savings and aging. Through a linear regression model using a set of 74 countries, the author estimated the savings rate in relation to income $(\mathrm{S} / \mathrm{Y})$ and savings per capita $(\mathrm{S} / \mathrm{N})$, using the dependency ratio of young people ${ }^{1}$ and the dependency ratio of elderly people ${ }^{2}$, as well as the economic growth rate and per capita income, as regressors. The author found that in both the total sample and the subset of developing countries, a greater proportion of young and elderly people had a negative effect on total savings, but with differing degrees of elasticity: a $1 \%$ increase in the proportion of young people reduced the savings rate four times more than a $1 \%$ increase in the proportion of elderly people.

Gupta (1975) sought to discover not only the direct effect of dependency ratios on the savings rate but also their indirect effects through variations in income. To do this, he applied the two-stage least squares model to 40 developing countries and found that the total effects of the dependency ratios were even greater than those found by Leff (1969).

However, while studies using aggregated data have found dissavings with increases in the dependency ratio of elderly people (Leff, 1969; Gupta, 1975; Wachtel, 1984; Bosworth et al., 1991), studies using individual data have found little statistical significance (Heller, 1989; Masson e Tryon, 1990). Seeking explanations for this difference, Weil (1994) used data from a 1984 American study entitled the "Panel Study of Income Dynamics" to examine the intergenerational relations among households. The hypothesis was that an elderly person might affect the savings not only of his or her own household but also the savings of other households. The results suggested that, assuming constant income, the prospect of an inheritance

1 The ratio between the population of youths ( 0 to 14 years of age) and the population of potentially economically active individuals (15 to 64 years of age).

2 The ratio between the population of elderly people ( 65 years or older) and the population of potentially economically active individuals (15 to 64 years of age). 
could increase consumption; that is, while an elderly person might not be spending savings, younger generations might reduce savings in expectation of receiving an inheritance.

Lee et al. (2000) attempt to explain the marked increase in the savings rate in Taiwan in the second half of the 20th century. Using a simulation model, they argue that the explanation for the phenomenon is the dramatic increase in life expectancy, which requires funding a longer period of retirement. Subsequent studies using panel data corroborated these findings in various countries: Bloom et al. (2003) note the exception that, while the rate of savings may be increasing across all ages, decades of growth in the proportion of elderly people may reduce aggregate savings; Kinugasa and Mason (2007) argue that the gains in savings due to people's increasing life expectancy are much higher than the gains due to the smaller proportion of young dependents.

Thus, Mason and Lee (2006) define the period in which the demographic transition contributes to an increase in savings as the second demographic bonus. In turn, Bloom et al. (2007) argue that longer life expectancy affects savings only in countries whose social security systems are capitalized but would not apply to countries that adopt a pay-as-you-go pension system, as is the case in Brazil. As the authors note, this is because the system of pay-as-you-go reduces individuals' concern for saving enough to support themselves in their old age.

Nonetheless, Neri et al. (1999) used a qualitative study conducted by the Brazilian Credit and Savings Association (Associação Brasileira de Crédito e Poupança - Abecip) in 1996 intended to examine the process of accumulation and dissipation of financial wealth over the life cycle, especially the need for assets in old age. The main reason for savings among the Brazilian elderly is precaution, with almost half of savers wanting to be prepared for any emergencies. Among young people, the most cited reason for saving was to accumulate funds for the future, which is consistent with the life cycle hypothesis. Finally, there was no evidence for a habit of saving to ensure the future of the next generation, indicating that the occasional inheritances left to family in the Brazilian context were unexpected rather than planned. Stampe (2013) estimates that, in Brazil, with population aging, consumption declines in some sectors but grows in others, making overall consumption stable at more advanced ages. 


\section{Methodology}

The economic definition of savings is the difference between income and consumption. However, it is difficult to apply this concept using the HBS data, as some part of each individual's consumption occurs within the household, making it impossible to arrive at an exact calculation of each individual family member's savings. Therefore, an initial estimate of savings and dissavings was arrived at by examining financial investments and withdrawals, since this information is available at the individual level, including savings accounts, fixed income funds, bank Certificates of Deposit, stock holdings and private pension funds. Those who invest sums greater than their withdrawals are assumed to be savers, while those who withdraw more than they invest are classified as dissavers.

Because this study focuses on individuals' private savings, another challenge is how to treat the acquisition of real estate, as many people consider the purchase of a primary home as a form of savings for retirement. Thus, a second scenario included in the category of savers those individuals who invested more in the purchase of homes and land than the total value of real estate property sold, while those who reduced the total value of their real estate holdings were considered dissavers.

Finally, a third and final scenario combined the first two, taking into account both financial transactions and real estate dealings. That is, savers were defined as individuals whose combined financial investments and real estate purchases exceeded their combined financial withdrawals and real estate sales.

Thus, in the first scenario (considering only financial transactions), micro-data from the HBS were used to calculate the sum of the investments and withdrawals made over the past 12 months by individual $i$, with the financial balance for the period given by the following equation:

$$
\text { Balance }_{i}=\text { Investments }_{i}-\text { Withdrawals }_{i}
$$

The dependent variable is then given by the following classification for each individual:

- If Balance $_{i}>0$, the individual was a saver over the past 12 months (category Saver).

- If Balance $_{i}<0$, the individual was a dissaver over the past 12 months 
(category Dissaver).

- If Balance $_{i}=0$, the individual was neither a saver nor a dissaver over the past 12 months (category NSND).

Note that according to the classification above, an individual whose total deposits and total withdrawals were equal would have a balance of zero. For example, someone who invested $\mathrm{R} \$ 1,000$ in stocks and withdrew $\mathrm{R} \$ 1,000$ from a savings account has a zero balance, being neither a saver nor a dissaver (NSND). By contrast, someone who invested $\mathrm{R} \$ 1,000$ in a bank $C D$ and withdrew $R \$ 800$ from a savings account is considered a saver because the balance is positive.

In the second scenario (real estate acquisition), the method is very similar, as it is also possible to identify the amounts spent and received in the real estate market over the last 12 months through the HBS, including both financed purchases and cash transactions. However, this case presents an additional complication, as the purchase or sale of a primary residence appears in the HBS as a collective transaction, making it impossible to attribute the acquisition or sale to a specific family member or members. Therefore, we assumed that the acquisition or sale of the property is conducted only by the head of household and his or her spouse (if applicable), dividing the value of the property proportionally according to the total income of these two family members. Finally, in the third scenario, which includes both financial and real estate transactions, the balance is derived simply by summing the other two scenarios.

Once the three categories (Saver, Dissaver and NSND) had been established for each scenario (financial, real estate and total transactions), a multinomial logit model was constructed, according to the equation below:

$$
P\left(y_{i}=j\right)=\frac{\exp \left(X_{i}^{\prime} \beta_{j}\right)}{\sum_{j=0}^{2} \exp \left(X_{i}^{\prime} \beta_{i}\right)}, j=0,1 \text { e } 2
$$

where $P\left(y_{i}=j\right)$ is the probability of individual $i$ being of category $j$ - assigning 1 for the Saver category and 2 for the dissaving category, while NSND is the reference category $0, X$ is the matrix of characteristics of individuals and $\beta_{j}$ is the vector of parameters to be estimated.

We can thus estimate, for each age, the probability that an individual is a saver or a dissaver. In the present work, the matrix $X$ was estimated using age and age squared as regressors, always applying probability 
weights ${ }^{3}$. In addition, in one of the sections of results, the estimates were tested with the presence of control variables for socioeconomic, educational and demographic characteristics, which when employed, assigned the national averages for the probability calculations.

\section{Results}

An initial descriptive analysis (Table 1) shows that between 2002/2003 and $2008 / 2009$, the number of savers declined in the financial scenario (from $6.2 \%$ to $5.7 \%$ ) but continued to grow in the real estate scenario (from $1.4 \%$ to $1.7 \%$ ). Therefore, adding the financial and real estate scenarios, the percentage of savers declined from its 2002/2003 level of $7.3 \%$ to $7.0 \%$ during the final period.

It is possible that the explanation for this decline in the number of savers between 2002/2003 and 2008/2009 lies in the economic context, as the 2008-2009 HBS was conducted during a global economic crisis to which the Brazilian government responded by stimulating consumption through tax reductions and public spending, while household income fell (TCU, 2009). However the 2002-2003 HBS was also collected in a period of uncertainty, when former President Lula was elected to his first term.

Table 1 also shows that in all the scenarios and all the periods analyzed, those who had depleted their savings over the previous 12 months had a higher mean age than those who had added to their savings. The savers, in turn, are older than those who were neither savers nor dissavers.

A simple analysis of the sample averages indicates that younger people are less likely to engage in financial and real estate transactions, the reasons for which will be explored in greater detail below. Moreover, the fact that dissavers are older than savers in all the periods and scenarios confirms the suspicion that the demographic transition could influence the net difference between savers and dissavers.

3 The probability weights (wi) are calculated by the IBGE such that the probability of an individual being drawn is equivalent to $1 / w i$, accounting for non-response. According to Pfeffermann (1996), inference in complex samples based on probability weighting generates point estimates that are approximately design unbiased, while the standard errors are biased. Based on this, we highlight the fact that the models estimated had sample sizes (n) of 128,193 in the 2008/2009 HBS and 119,323 in the 2002/2003 HBS. Thus, since the inferences are for the entire research coverage area, the sample sizes are large enough to generate accurate point estimates. 
Table 1 Percentages of Savers, Dissavers and NSND, with their respective mean ages, by scenario, 2002/2003 and 2008/2009

\begin{tabular}{|c|c|c|c|c|c|c|c|}
\hline Scenario & HBS & Category & $\begin{array}{r}N(\text { Un- } \\
\text { weighted) }\end{array}$ & $\begin{array}{r}\mathrm{N} \\
\text { (Weighted) }\end{array}$ & $\begin{array}{r}\text { Percent- } \\
\text { age }\end{array}$ & $\begin{array}{r}\text { Mean } \\
\text { age }\end{array}$ & SD \\
\hline \multirow{6}{*}{ Financial } & \multirow{3}{*}{$\begin{array}{r}2008 / \\
2009\end{array}$} & Saver & 8,090 & $7,920,146$ & $5.7 \%$ & 40.11 & 15.86 \\
\hline & & Dissaver & 2,767 & $2,722,661$ & $2.0 \%$ & 44.77 & 17.24 \\
\hline & & NSND & 138,685 & $128,777,566$ & $92.4 \%$ & 33.81 & 17.99 \\
\hline & \multirow{3}{*}{$\begin{array}{r}2002 / \\
2003\end{array}$} & Saver & 6,325 & $9,507,874$ & $6.2 \%$ & 43.19 & 15.98 \\
\hline & & Dissaver & 1,976 & $3,423,428$ & $2.2 \%$ & 47.67 & 16.79 \\
\hline & & NSND & 133,753 & $139,731,234$ & $91.5 \%$ & 36.20 & 18.70 \\
\hline \multirow{6}{*}{$\begin{array}{l}\text { Real } \\
\text { Estate }\end{array}$} & \multirow{3}{*}{$\begin{array}{r}2008 / \\
2009\end{array}$} & Saver & 1,700 & $2,418,936$ & $1.7 \%$ & 38.62 & 12.91 \\
\hline & & Dissaver & 466 & 724,840 & $0.5 \%$ & 45.09 & 13.91 \\
\hline & & NSND & 147,376 & $136,276,597$ & $97.7 \%$ & 34.25 & 18.05 \\
\hline & \multirow{3}{*}{$\begin{array}{r}2002 / \\
2003\end{array}$} & Saver & 2,344 & $2,171,023$ & $1.4 \%$ & 40.41 & 13.47 \\
\hline & & Dissaver & 843 & 509,232 & $0.3 \%$ & 48.12 & 14.97 \\
\hline & & NSND & 138,867 & $149,982,281$ & $98.2 \%$ & 36.80 & 18.71 \\
\hline \multirow{6}{*}{$\begin{array}{l}\text { Financial } \\
+ \text { Real } \\
\text { Estate }\end{array}$} & \multirow{3}{*}{$\begin{array}{r}2008 / \\
2009\end{array}$} & Saver & 9,376 & $9,803,794$ & $7.0 \%$ & 39.65 & 15.27 \\
\hline & & Dissaver & 3,071 & $3,249,288$ & $2.3 \%$ & 44.95 & 16.75 \\
\hline & & NSND & 137,095 & $126,367,291$ & $90.6 \%$ & 33.70 & 18.05 \\
\hline & \multirow{3}{*}{$\begin{array}{r}2002 / \\
2003\end{array}$} & Saver & 8,163 & $11,109,313$ & $7.3 \%$ & 42.64 & 15.65 \\
\hline & & Dissaver & 2,666 & $3,677,349$ & $2.4 \%$ & 48.11 & 16.73 \\
\hline & & NSND & 131,225 & $137,875,874$ & $90.3 \%$ & 36.13 & 18.74 \\
\hline
\end{tabular}

Source of raw data: IBGE (micro-data of the Household Budget Surveys of 2002/2003 and 2008/2009). Note: $N$ (unweighted) represents the number of respondents in the study in each category, while $N$ (weighted) represents the number of individuals in the Brazilian population represented by these respondents (applying probability weights). All the other columns are weighted.

In the next two subsections, multinomial logit models are used to more accurately measure the effects of age on an individual's propensity to save. First, estimates of the propensity to save or dissave are calculated for each of the three scenarios without using control variables, that is, a real scenario of the ages most and least likely to save in Brazil.

In the second subsection, however, control variables are used in an effort to understand how the propensity to save or dissave by age would behave if variables such as income, educational level, or gender, were held constant. 


\subsection{Results without the use of controls}

Table 2 reports the estimates of the multinomial logit model coefficients for the three scenarios, using only age and age squared as explanatory variables and NSND as the reference category. In all scenarios and periods, the odds ratios of being a "Saver" of being a "Dissaver", relative to being an NSND, have an association with age that appears as an open-bottom parabola because the coefficients are positive for age and negative for agesquared, indicating that there is a maximum point in both bases. Note the relative similarity among the coefficients in the two periods studied.

Table 2 Coefficients estimated for the multinomial logit model, using Neither Saver Nor Dissaver over the Past 12 Months as the reference category, Brazil, 2002/2003 and 2008/2009

\begin{tabular}{lllrr|r}
\hline \multirow{2}{*}{ Scenario } & \multirow{2}{*}{ Coefficient } & & Saver/NSND & \multicolumn{2}{r}{ Dissaver/NSND } \\
\cline { 2 - 6 } & & $\mathbf{2 0 0 8 / 2 0 0 9}$ & $\mathbf{2 0 0 2 / 2 0 0 3}$ & $\mathbf{2 0 0 8 / 2 0 0 9}$ & $\mathbf{2 0 0 2 / 2 0 0 3}$ \\
\hline \multirow{3}{*}{ Financial } & Intercept & $-4.2262^{* * *}$ & $-4.0047^{* * *}$ & $-5.832^{* * *}$ & $-5.4391^{* * *}$ \\
\cline { 2 - 6 } & Age & $0.0735^{* * *}$ & $0.0637^{* * *}$ & $0.0817^{* * *}$ & $0.0638^{* * *}$ \\
\cline { 2 - 6 } & Age^2 & $-0.0007^{* * *}$ & $-0.0006^{* * *}$ & $-0.0006^{* * *}$ & $-0.0004^{* * *}$ \\
\hline \multirow{3}{*}{ Real Estate } & Intercept & $-6.7638^{* * *}$ & $-6.6382^{* * *}$ & $-9.228^{* * *}$ & $-9.3091^{* * *}$ \\
\cline { 2 - 6 } & Age & $0.1405^{* * *}$ & $0.1473^{* * *}$ & $0.1454^{* * *}$ & $0.1817^{* * *}$ \\
\cline { 2 - 6 } & Age^2 & $-0.0016^{* * *}$ & $-0.0017^{* * *}$ & $-0.0012^{* * *}$ & $-0.0017^{* * *}$ \\
\hline \multirow{2}{*}{ Financial + } \\
Real Estate & Intercept & $-4.1622^{* * *}$ & $-4.0257^{* * *}$ & $-5.92^{* * *}$ & $-5.653^{* * *}$ \\
\cline { 2 - 6 } & Age & $0.0815^{* * *}$ & $0.0795^{* * *}$ & $0.088^{* * *}$ & $0.0832^{* * *}$ \\
\cline { 2 - 6 } & Age^2 & $-0.0008^{* * *}$ & $-0.0008^{* * *}$ & $-0.0006^{* * *}$ & $-0.0006^{* * *}$ \\
\hline Observations & & 128,193 & 119,323 & 128,193 & 119,323 \\
\hline
\end{tabular}

Source of raw data: IBGE (micro-data from the Household Budget Surveys of 2002/2003 and 2008/2009. *** Coefficient is statistically significant (at the $0.1 \%$ level applying Wald Test).

Note: All results are obtained by applying probability weights.

By transforming the coefficients, as described in Section 3, we can calculate the estimated probability that an individual will be a saver or dissaver, given his or her age, as shown in Figure 1. The probability of saving remains fairly stable during the periods studied in both the financial scenario (with a peak at age 54 in 2008/2009) and the real estate scenario (where the age with the greatest propensity for savings was 43 in the final period). 
In contrast, the likelihood of dissaving, which always peaks at an older age than that of saving, occurred later in the 2008/2009 HBS (with the exception being in the financial scenario). Thus, in the final period, the peak occurred at age 69 in the financial scenario, at age 59 in the real estate scenario, and at age 69 in the scenario that combines financial and real estate transactions.

Figure 1 Probability of saving, probability of dissaving and net difference, over a 12-month period, Brazil, 2002/2003 and 2008/2009

\section{Financial and Retirement Savings}

2002-2003

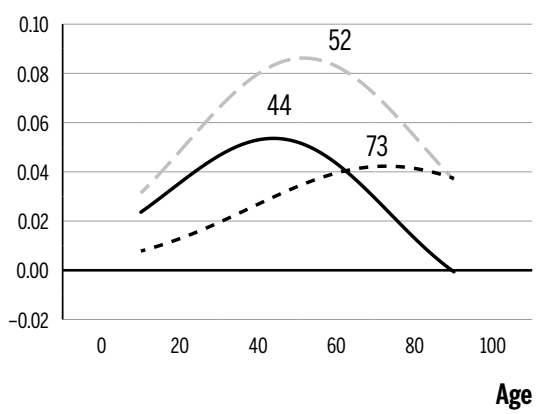

\section{Real State Investiments}

$2002-2003$

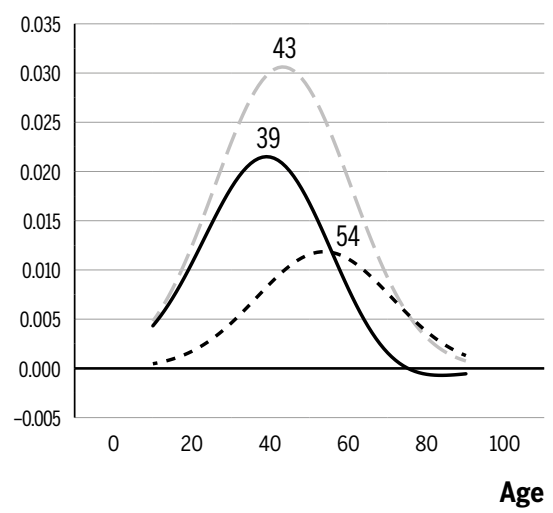

- - - Probability of being a saver

Difference between the probabilities
2008-2009

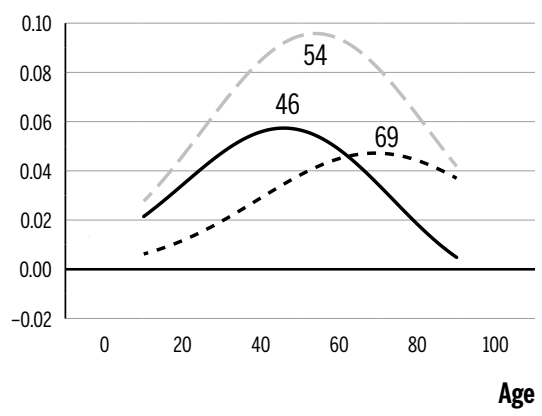

2008-2009

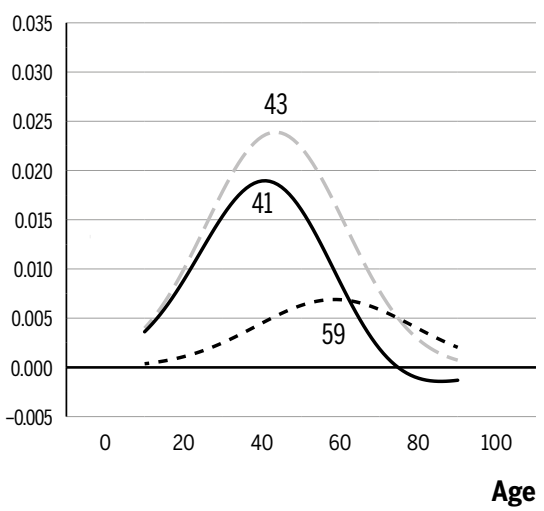

. . . . Probability of being a dissaver 
Figure 1 (continuation)

\section{Total Investiments}

$2002-2003$

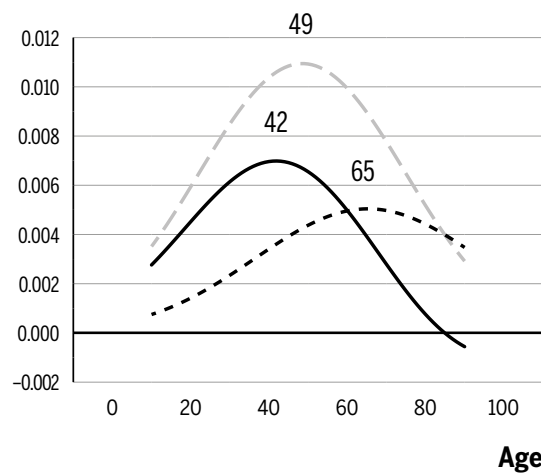

2008-2009

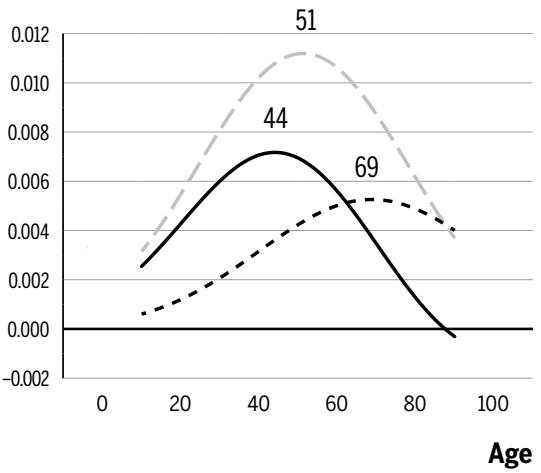

Fonte: Prepared by the author applying the microdata of 2002/2003, 2008/2009 HBS (IBGE) Note: All results are obtained by applying probability weights.

As a result, the net difference between the two probabilities in the scenario that combines financial and real estate transactions has also advanced over time, rising from 42 to 44 years of age. This figure deserves particular attention in the analysis because it represents the net effect of new savers. For example, if of every 100 individuals at age $i$, eight are savers and five are dissavers, the net balance is three additional savers.

According to the Brazilian Institute of Geography and Statistics (Instituto Brasileiro de Geografia e Estatística - IBGE) (2013), the mean age of the population between 16 and 90 years was 41 in 2015; it is increasing and expected to reach 45 in 2030, as shown in Figure 2. Thus, because the probability of saving in the combined scenario (financial + real estate) reached its maximum at 44 years in 2008/2009, with a tendency to rise from one survey to the next, there are indications that, at least until 2030, the population structure should contribute to a rise in the percentage of savers, as Bloom (2010) has also observed.

In fact, the projections for 2045 , with a mean age of 49 years, could also represent a positive contribution to private savings because the age at maximum savings may be higher, as the trend shows. If the trend continues, the demographic structure would begin to have a negative effect on 
the number of savers beginning in 2060, when the mean age reaches 52 years and a large percentage of the population is elderly.

Figure 2 Projections by age of the Brazilian population between 16 and 90 years old, with their respective Mean Ages (MA), 2015 to 2060

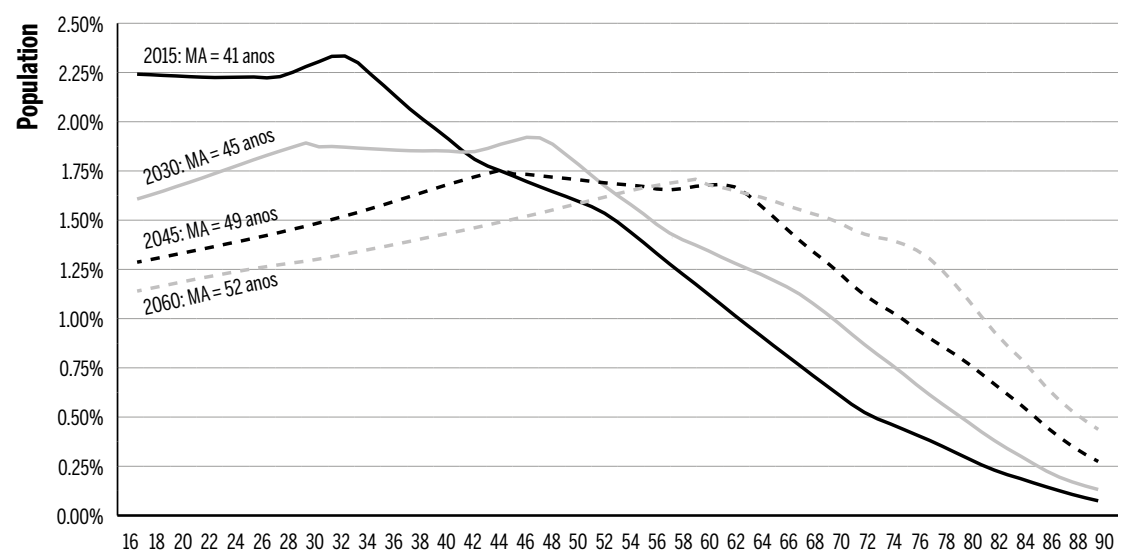

Age

Source: IBGE - Population Projections (2013 Revision).

\subsection{Results with the use of controls}

The previous subsection demonstrated that in the two periods examined, there is a quadratic relationship between age and the net difference in the probabilities of saving and dissaving, in keeping with the life cycle hypothesis: people tend to save less during their youth, save most during adulthood, and then save less again after they move into old age. However, if everyone, regardless of age, had the same income, level of education, gender, and so forth, would this relationship change?

To answer this question, the present subsection recalculated the same dependent variable but with the following controls: the logarithm of the individual's annual income, the logarithm of household income per capita, the number of household members, years of education, gender and two dummies (whether the person is a civil servant or an employee of a private company). Table 3 shows the estimated coefficients using the multinomial logit model. 
Table 3 Coefficients estimated for the multinomial logit model using Neither Saver Nor Dissaver over the past 12 months as the reference category, Brazil, 2002/2003 and 2008/2009

\begin{tabular}{|c|c|c|c|c|c|}
\hline \multirow[t]{2}{*}{ Scenario } & \multirow[t]{2}{*}{ Coefficient } & \multicolumn{2}{|r|}{ Saver/NSND } & \multicolumn{2}{|c|}{ Dissaver/NSND } \\
\hline & & $2008 / 2009$ & $2002 / 2003$ & $2008 / 2009$ & $2002 / 2003$ \\
\hline \multirow{10}{*}{ Financial } & Intercept & $-9.4187^{* * *}$ & $-7.7426^{* * *}$ & $-10.6728^{* * *}$ & $-9.8538^{* * *}$ \\
\hline & Number of residents & $-0.0758^{* * *}$ & $-0.0482^{* * *}$ & $-0.0517^{* * *}$ & $-0.004^{* * *}$ \\
\hline & Ln of annual income & $0.3894^{* * *}$ & $0.383^{* * *}$ & $0.2612^{* * *}$ & $0.266^{* * *}$ \\
\hline & Ln of annual Pc Income & $0.4876^{* * *}$ & $0.3571^{* * *}$ & $0.5399 * * *$ & $0.5177^{* * *}$ \\
\hline & Years of education & $0.038^{* * *}$ & $0.0445 * * *$ & $0.0346^{* * *}$ & $0.0349 * * *$ \\
\hline & Male & $0.006^{* * *}$ & $0.1046^{* * *}$ & $0.2631^{* * *}$ & $0.1537^{* * *}$ \\
\hline & Age & $0.0055^{* * *}$ & $-0.0167^{* * *}$ & $0.036^{* * *}$ & $0.0112^{* * *}$ \\
\hline & Age`2 & $-0.0001^{* * *}$ & $0.0002^{* * *}$ & $-0.0002^{* * *}$ & $0.0001^{* * *}$ \\
\hline & Private comp. Employee & $0.1798^{* * *}$ & $0.123^{* * *}$ & $-0.044^{* * *}$ & $0.2048 * * *$ \\
\hline & Civil servant & $0.1007^{* * *}$ & $-0.1224^{* * *}$ & $-0.1514^{* * *}$ & $-0.5638^{* * *}$ \\
\hline \multirow{10}{*}{$\begin{array}{l}\text { Real } \\
\text { Estate }\end{array}$} & Intercept & $-11.6872^{* * *}$ & $-9.3117^{* * *}$ & $-17.4993^{* * *}$ & $-15.6088^{* * *}$ \\
\hline & Number of residents & $0.0059 * * *$ & $-0.0471^{* * *}$ & $0.17^{* * *}$ & $0.1483^{* * *}$ \\
\hline & Ln of annual income & $0.3272^{* * *}$ & $0.2748^{* * *}$ & $0.1101^{* * *}$ & $0.1152^{* * *}$ \\
\hline & Ln of annual Pc Income & $0.6044^{* * *}$ & $0.4247^{* * *}$ & $1.3917^{* * *}$ & $0.9919^{* * *}$ \\
\hline & Years of education & $-0.0314^{* * *}$ & $-0.0422^{* * *}$ & $-0.1702^{* * *}$ & $-0.0902^{* * *}$ \\
\hline & Male & $-0.0585^{* * *}$ & $0.1408^{* * *}$ & $0.8474^{* * *}$ & $0.905^{* * *}$ \\
\hline & Age & $0.0791^{* * *}$ & $0.0791^{* * *}$ & $0.0955^{* * *}$ & $0.1403^{* * *}$ \\
\hline & Age`2 & $-0.0012^{* * *}$ & $-0.0011^{* * *}$ & $-0.0011^{* * *}$ & $-0.0014^{* * *}$ \\
\hline & Private comp. Employee & $-0.063^{* * *}$ & $-0.0306^{* * *}$ & $-0.5905^{* * *}$ & $-0.1324 * * *$ \\
\hline & Civil servant & $-0.2987^{* * *}$ & $0.0875^{* * *}$ & $0.1721^{* * *}$ & $-0.0372^{* * *}$ \\
\hline \multirow{11}{*}{$\begin{array}{l}\text { Financial } \\
+ \text { Real } \\
\text { Estate }\end{array}$} & Intercept & $-9.4564^{* * *}$ & $-7.6487^{* * *}$ & $-11.111^{* * *}$ & $-10.5672^{* * *}$ \\
\hline & Number of residents & $-0.0613^{* * *}$ & $-0.0496^{* * *}$ & $-0.0294^{* * *}$ & $0.031^{* * *}$ \\
\hline & Ln of annual income & $0.3883^{* * *}$ & $0.3693^{* * *}$ & $0.2291 * * *$ & $0.249 * * *$ \\
\hline & Ln of annual Pc Income & $0.5152^{* * *}$ & $0.3877^{* * *}$ & $0.6591 * * *$ & $0.6336^{* * *}$ \\
\hline & Years of education & $0.0298^{* * *}$ & $0.0233^{* * *}$ & $0.0077^{* * *}$ & $0.0073^{* * *}$ \\
\hline & Male & $-0.0232^{* * *}$ & $0.1118^{* * *}$ & $0.347^{* * *}$ & $0.3228^{* * *}$ \\
\hline & Age & $0.0158^{* * *}$ & $0.0026^{* * *}$ & $0.0446^{* * *}$ & $0.0323^{* * *}$ \\
\hline & Age^2 & $-0.0002^{* * *}$ & $-0.0001^{* * *}$ & $-0.0003^{* * *}$ & $-0.0002^{* * *}$ \\
\hline & Private comp. Employee & $0.1319^{* * *}$ & $0.0843^{* * *}$ & $-0.0977^{* * *}$ & $0.0864^{* * *}$ \\
\hline & Civil servant & $0.0137^{* * *}$ & $-0.0533^{* * *}$ & $-0.0969 * * *$ & $-0.4463^{* * *}$ \\
\hline & Observations & 128,193 & 119,323 & 128,193 & 119,323 \\
\hline
\end{tabular}

Source of raw data: IBGE (micro-data from the Household Budget Surveys of 2002/2003 and 2008/2009. 
*** Coefficient is statistically significant (at the $0.1 \%$ level applying Wald Test).

Note: All results are obtained by applying probability weights.

By applying the same transformation as in the previous subsection and attributing the national average to the control variables, we can calculate the probability that a person is a saver or dissaver, given the person's age. Figure 3 shows a marked change in behavior in the financial scenario, as the net difference between the probabilities is greater in the youngest age group. In other words, if young people had the same income and other characteristics as people in the more mature group, they would be the group with the greatest difference between savers and dissavers.

In the real estate scenario, however, the analysis changes, returning to the maximum points for savers, dissavers and net differences. This means that even when all the controls are in place, there would be a middle age group, consisting of people between 34 and 44 years of age, with a greater propensity to purchase or sell real estate, with the net difference peaking at 33 years old.

Figure 3 Probability of saving, probability of dissaving and net difference over a 12-month period, for an individual with the average national profile for Brazil, 2002/2003 and 2008/2009

\section{Financial and Retirement Savings}

2002-2003

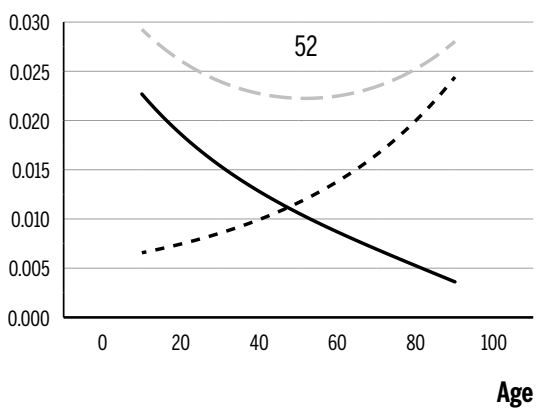

- - - Probability of being a saver

Difference between the probabilities

\section{8-2009}

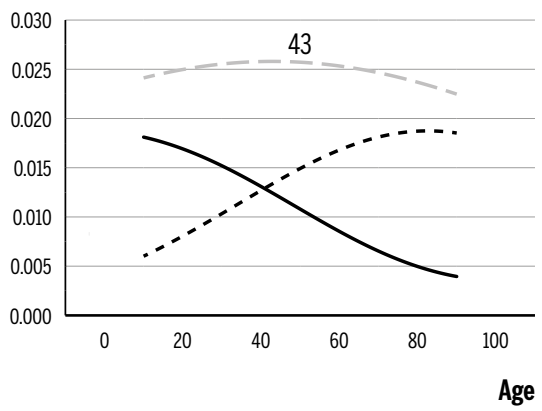

- Probability of being a dissaver

(continues on the next page) 
Figure 3 (continuation)

\section{Real State Investiments}

$2002-2003$

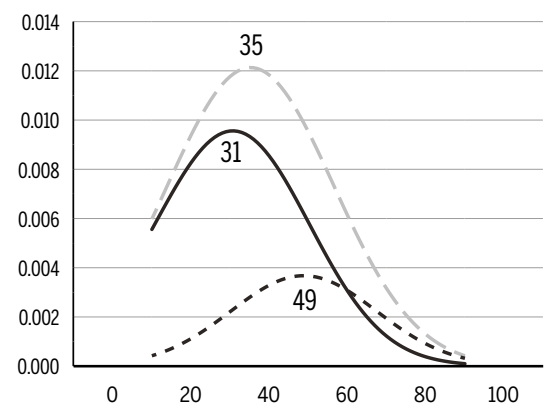

Age
2008-2009

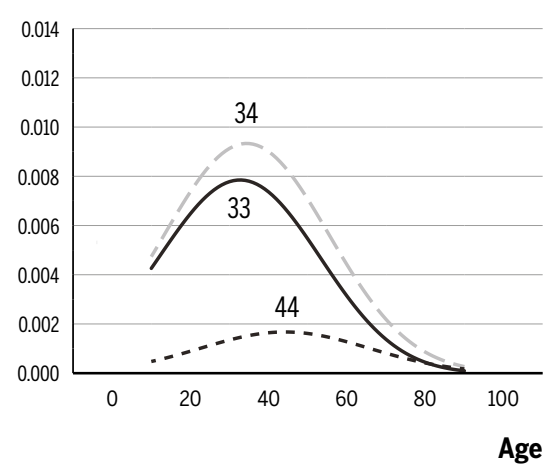

\section{Total Investiments}

2002-2003

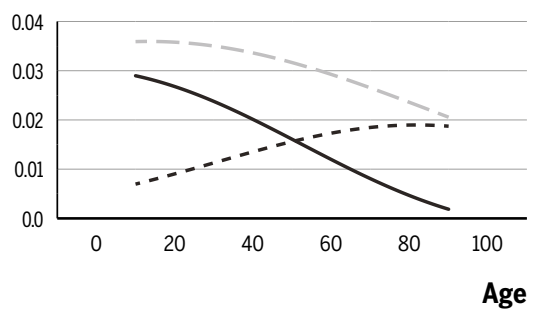

2008-2009

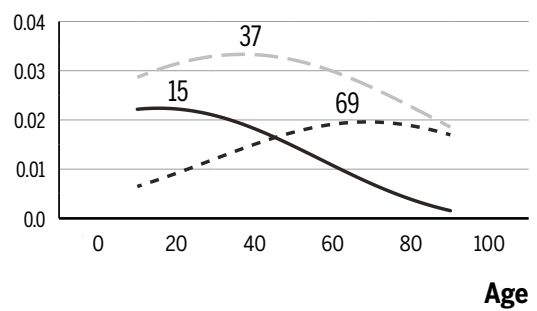

Source: Prepared by the author applying the microdata of 2002/2003, 2008/2009 HBS (IBGE) Note: All results were obtained by applying probability weights.

The results in this section show that young people would show a high propensity to save if their other characteristics resembled those of older generations. The explanation for this probably lies in their long life expectancy and their desire to maintain an appropriate standard of living throughout the entire period. 


\section{Conclusions}

For both periods analyzed, the results obtained for savings in the financial scenario and in the combined financial and real estate scenario are consistent with the life cycle hypothesis. When no control variables are used, the propensity to save among young people is low; it increases among mature adults and declines again in old age. The main cause of the low savings rate among young people is that their needs exceed their income, while older people deplete the savings they accumulated during their adult lives to maintain their consumption pattern over their lifespan.

When control variables such as income are introduced, this hypothesis is strengthened, as young people would become the biggest savers if they had the same characteristics as individuals of other ages. In other words, young people save less not as a matter of choice but due to their high needs and budget constraints. Elderly people, by contrast, are less likely to save even when control variables are introduced, once again corroborating the life cycle hypothesis.

Without the use of controls, the two periods showed very similar results in the financial scenario. The age at maximum individuals' propensity to save varied between 52 years old in the first household budget survey to 54 years old in the final survey. The net difference increased from 44 to 46 years of age, while the maximum probability of being a saver remained at approximately $10 \%$ in both surveys. These results are similar to the conclusions reached by Bloom et al. (2007), who show that the effect of longer life expectancy on savings is very small in countries where the pension is based on a pay-as-you-go system.

Although the elderly have a lower propensity to save, there are indications that, at least for the next several decades, the aging of the population should increase the number of savers because the largest segment of Brazil's population structure is still approaching the age at which individuals are most likely to save. However, as Bloom et al. (2010) have also shown, beyond that point, the large number of elderly individuals is expected to weigh negatively on the number of net savers. 


\section{References}

ALBIERI, S.; BIANCHINI, Z. M. Principais aspectos de amostragem das pesquisas domiciliares do IBGE-Revisão 2015. Rio de Janeiro: IBGE. Texto para Discussão, n. 55, 2015.

ANDO, A.; MODIGLIANI, F. The "life cycle" hypothesis of saving: Aggregate implications and tests. The American Economic Review, v. 53, n. 1, p. 55-84, mar. 1963.

BLOOM, D. E.; CANNING, D.; GRAHAM, B. Longevity and life-cycle savings. The Scandinavian Journal of Economics, v. 105, n. 3, p. 319-338, sep. 2003.

BLOOM, D. E.; CANNING, D.; MANSFIELD, R. K.; MOORE, M. Demographic change, social security systems, and savings. Journal of Monetary Economics, v. 54, n. 1, p. 92-114, jan. 2007.

BOSWORTH, B.; BURTLESS, G.; SABELHAUS, J.; POTERBA, J. M.; SUMMERS, L. H. The decline in saving: Evidence from household surveys. Brookings Papers on Economic Activity, v. 1991, n. 1, 183-256, 1991.

FRIEDMAN, M. The permanent income hypothesis. In: A theory of the Consumption Function. Princeton University Press. p. 20-37. 1957.

GUPTA, K. L. Foreign capital inflows, dependency burden, and saving rates in developing countries: A simultaneous equation model. Kyklos, v. 28, n. 2, p. 358-374, jan. 1975.

HELLER, P. S. Aging, Savings, and Pensions in the Group of Seven Countries: 1980-2025. Journal of Public Policy, v. 9, n. 2, p. 127-155, apr. 1989.

KINUGASA, T.; MASON, A. Why countries become wealthy: the effects of adult longevity on saving. World Development, v. 35, n. 1, p. 1-23, 2007.

LEE, R.; MASON, A.; MILLER, T. Life cycle saving and the demographic transition: The case of Taiwan. Population and Development Review, v. 26, supl. 1, p. 194-219, 2000.

LEFF, N. H. Dependency rates and savings rates. The American Economic Review, v. 59, n. 5, p. 886-896, dec. 1969.

MASON, A.; LEE, R. Reform and support systems for the elderly in developing countries: capturing the second demographic dividend. Genus, v. 62, n. 2, p. 11-35, apr. 2006.

MASSON, P. R.; TRYON, R. W. Macroeconomic effects of projected population aging in industrial countries. Staff Papers, v. 37, n. 3, p. 453-485, 1990.

MODIGLIANI, F.; ANDO, A. K. Tests of the life cycle hypothesis of savings: comments and suggestions. Oxford Bulletin of Economics and Statistics, v. 19, n. 2, 99-124, may. 1957.

NERI, M.; CARVALHO, K.; NASCIMENTO, M. Ciclo da vida e motivações financeiras (com especial atenção aos idosos brasileiros). Ipea. Texto para discussão n 691, Rio de janeiro. 1999.

PFEFFERMANN, D. The use of sampling weights for survey data analysis. Statistical methods in medical research, v. 5, n. 3, p. 239-261, 1996.

SOLOW, R. M. A contribution to the theory of economic growth. The Quarterly Journal of Economics, v. 70, n. 1, p. 65-94, feb. 1956.

STAMPE, M. Z. Três Ensaios Sobre Mudança Demográfica e Seus Impactos nas Economias Brasileira e Gaúcha. Tese de doutorado. Universidade Federal do Rio Grande do Sul, Programa de Pós Graduação em Economia. 2013. 
TCU. Tribunal de Contas da União. Ações do Governo Para Reduzir os Efeitos da Crise. Versão simplificada das Contas do Governo da República, 2009. Disponível em: http://portal. tcu.gov.br/tcu/paginas/contas_governo/contas_2009/Textos/Ficha\%201\%20-\%20Analise\%20da\%20Crise.pdf. 2009.

WACHTEL, P. Household saving and demographic change 1950-2050. Research in Population Economics, v. 5, p. 217-33. 1984.

WEIL, D. N. The saving of the elderly in micro and macro data. The Quarterly Journal of Economics, v. 109, n. 1, p. 55-81, feb. 1994.

\author{
About the authors \\ PedroTononZuanazzi-pedro-zuanazzi@planejamento.rs.gov.br \\ Departamento de Economia e Estatística, Secretaria de Planejamento, Governança e Gestão do Rio Grande do Sul, Porto \\ Alegre, RS, Brasil. \\ ORCID: https://orcid.org/0000-0001-6693-2415. \\ AdelarFochezatto-adelar@pucrs.br \\ Programa de Pós-Graduação em Economia, Escola de Negócios, Pontifícia Universidade Católica do Rio Grande do Sul, \\ Porto Alegre, RS, Brasil. \\ ORCID: https://orcid.org/0000-0001-7192-3986. \\ Conselho Nacional de Desenvolvimento Científico e Tecnológico-CNPq/Processo: 310796/2018-0.
}

\title{
About the article
}

Submission received on July 09, 2018. Approved for publication on January 24, 2020. 